\title{
INANIMATE NATURE OF THE KOLA PENINSULA: SELECTED ADVANTAGES AND POSSIBILITIES OF PROTECTION AS A GEOPARK
}

\author{
Krivovichev S.V., Zhigunova G.V., Huber M.., Kovalevsky M.V. ${ }^{1}$, Novikov A.A. ${ }^{3}$, Boglaev V.E. ${ }^{4}$, \\ Bayanova T.B. ${ }^{1}$, Belevskikh T.V. ${ }^{2}$, Yakovleva O.A. ${ }^{3}$ \\ ${ }^{1}$ Geological Institute of the Kola Science Centre, Russian Academy of Sciences, Apatity, Russia, krivovi- \\ chev@admksc.apatity.ru,koval@geoksc.apatity.ru,bayanova@geoksc.apatity.ru \\ ${ }^{2}$ Murmansk Arctic State University, Murmansk,Russia, galina-zhigunova@yandex.ru \\ ${ }^{3}$ Maria Curie-Skłodowska University,_Lublin,Poland,mhuber@poczta.umcs.lublin.pl \\ ${ }^{4}$ «Fires of Murmansk», Murmansk, Russia \\ *corresponding author
}

\begin{abstract}
The article highlights selected objects of the Kola Peninsula with unique geological values promising to become geoparks. These are a metamorphic complex of the Hadaic age from the Murmansk vicinity, the BIF formation iron ore in the Olenegorsk area, stratified basic-ultrabasic intrusions containing PGE mineralization from the Monchegorsk vicinity, the Lapland Granulite Belt - the Proterozoic collision zone in the Kandalaksha area, the Eocambrian sedimentary complexes of the Rybachy and Tersky coasts, complexes of alkaline rocks in the massifs of Khibiny, Lovozero and Afrikanda. Provided below is their geological structure, natural environment, historical and cultural background. The article discusses conditions of creating geoparks in the target areas, i.e. the current state of tourism infrastructure, the legal situation of protected objects, possibilities of the Kola tourism development based on known examples in Kirovsk and the risk of increased tourist traffic in the discussed areas.
\end{abstract}

Key words: geotourism, geopark, Kola Peninsula, KSC RAN, MAGTU.

\section{Introduction}

The Kola Peninsula is the northeastern part of Fennoscandia almost entirely located inside the Arctic Circle. Within the administrative borders of the Murmansk region, there is a peninsula and small fragments of other geographical regions (Lapland in the west, Karelia in the south). The Kola Peninsula is bordered by the Barents Sea and White Sea (in the north, east and south) and neighbors with Norway and Finland. Geologically, this region is the northern part of the Fennoscandian craton, occurring here as the Baltic Shield. It is an area with about 100 thousand [17] lakes and various geomorphological forms associated with long-term weathering denudation and imposed degeneration processes in the Pleistocene/Holocene. It has a lot of old rock formations with numerous exposures within the massifs that tectonically rejuvenated during many consolidation processes. The Kola Peninsula is also characterized by the wealth of rock formations of various origins. There are numerous archaic blocks of highly synthesized granitogneisess, often metamorphosed in amphibolite and granite facies with green belt stripes and numerous intrusions between them [17]. Many occurrences of rare deposits of BIF, PGE, LCT, alkaline, as well as rocks containing $\mathrm{Cr}, \mathrm{Ni}, \mathrm{Cu}, \mathrm{Fe}$ ores and other elements were found on Kola. New discoveries of minerals in the region have been testified in numerous reports $[4,12,17]$.

The Kola Peninsula is also an attractive piece of the Arctic nature, but with a milder climate because of the warm current that makes Murmansk the northernmost port in the Barents Sea and Russia. This region has an interesting and multicultural history connected with the Lapps, Sami, Lopars and Karelian peoples, as well as a huge cultural heritage of the Russians, whose presence is a very important cultural factor. Finally, there are numerous technological facilities, such as the world-deepest borehole exceeding the depth of $12 \mathrm{~km}[1,2,3]$.

All the above-mentioned factors indicate a high tourist potential of the Kola Peninsula, its cultural and geological value, making it worth protecting and available to tourists as a geopark. The burning issue is the possibility of creating such an object in the nearest future, if at all. The reader will find the answer to this question in the article discussion. 


\section{Methods}

In the past ten years of reconnaissance, the authors made a number of field expeditions, inventoried the most important geological massifs, made geological sketches of their structure, sampled rocks and performed numerous geological and other studies [17]. The work resulted into a list of geological, tourist and natural-cultural values along with a spatial development study. The study revealed the need of installing tourist infrastructure and creating effective protection of the target areas. Table 1 provides the list of the analyzed objects.

Table 1. List of selected objects of the Murmansk region.

\begin{tabular}{|c|c|c|c|}
\hline LP & Name & Characteristics & Comments \\
\hline 1 & Murmansk & $\begin{array}{l}\text { A complex of metamorphites aged } 3.75 \mathrm{Ga} \text { from the Murmansk area, the } \\
\text { oldest formation in Europe formed in the ancient ocean. The possibility } \\
\text { of tracing it and numerous secondary processes in the city. Easy access. }\end{array}$ & Exposure in the city \\
\hline 2 & $\begin{array}{l}\text { Moncheplu- } \\
\text { ton }\end{array}$ & $\begin{array}{l}\text { A layered intrusion of basic-ultrabasic rocks containing PGE mineraliza- } \\
\text { tion. The possibility of tracing its structure on the surface in situ. Interest- } \\
\text { ing nature, especially in the western part of the massif. Easy access. }\end{array}$ & \multirow{2}{*}{$\begin{array}{l}\text { Area partly exclud- } \\
\text { ed from protection } \\
\text { by operating activi- } \\
\text { ties }\end{array}$} \\
\hline 3 & Olenegorsk & $\begin{array}{l}\text { An iron ores formation containing precious metals. The possibility of rec- } \\
\text { reating the sedimentary conditions in the archaic ocean, a key role in the } \\
\text { formation of the Earth's atmosphere. There are numerous lakes, swamp } \\
\text { vegetation, spruce and pine forests in the area. }\end{array}$ & \\
\hline 4 & $\begin{array}{l}\text { Lapland } \\
\text { Granulite } \\
\text { Belt }\end{array}$ & $\begin{array}{l}\text { The Proterozoic collision zone in the vicinity of Kandalaksha. The col- } \\
\text { lision zone can be traced in small exposures. An area with interesting } \\
\text { constructions, close to the city. Partially adjusted for tourists. Valuable } \\
\text { historical heritage, souvenirs and picturesque nature. }\end{array}$ & \multirow{2}{*}{ Poor infrastructure } \\
\hline 5 & $\begin{array}{l}\text { Rybachy } \\
\text { Peninsula, } \\
\text { Tersky coast }\end{array}$ & $\begin{array}{l}\text { The Eocambrian sedimentary complexes of the Rybachy Peninsula and } \\
\text { the Tersky Coast. Picturesque rocks and weathering forms, valuable areas } \\
\text { of the Russian culture. }\end{array}$ & \\
\hline 6 & Khibiny & $\begin{array}{l}\text { A complex of alkaline rocks in the Khibiny massif. A large rock massif } \\
\text { with the Alpine landscape. A partially operating tourist base. A number } \\
\text { of tourist attractions. }\end{array}$ & \multirow{2}{*}{$\begin{array}{l}\text { Area partly exclud- } \\
\text { ed from protection } \\
\text { by operating activi- } \\
\text { ties }\end{array}$} \\
\hline 7 & Lovozero & $\begin{array}{l}\text { A complex of alkaline rocks in the Lovozero massif. Its large area and } \\
\text { picturesque landscape allow creating tourist facilities. Peculiar vegeta- } \\
\text { tion, especially amidst the massif. }\end{array}$ & \\
\hline 8 & Afrikanda & $\begin{array}{l}\text { A complex of ultrabasic-alkaline rocks in the massif of Afrikanda. } \\
\text { Changes can be traced in a small area of the intrusion. }\end{array}$ & Poor infrastructure \\
\hline
\end{tabular}

\section{Results}

Provided below are geological and natural values of the discussed objects and their short geological, natural, historical and cultural characteristics.

A complex of metamorphites of the Hadaic age in the vicinity of Murmansk. This complex is bestexposed near Murmansk, by the Monument to the Unknown Soldier («Alyosha») and around the ring road also known as «Leningradka», extending some $30 \mathrm{~km}$ in the eastern part of the city. This road has been recently renovated. It has numerous trenches that allow observing rock exposures and their diversity in the area. There are also many interesting places in the city, e.g. at the Geroev Severomortsev Street there are two complexes of different-age gaps intersecting each other at an angle of about $45^{\circ}$. The forest area is wellvisible in the city and its surroundings. At the hill tops it turns into tundra. In the out-flow zones, there are numerous water-bearing reservoirs in faults, commonly overgrown by vegetation.

Layered basic intrusions containing PGE mineralization in the vicinity of Monchegorsk. Near Monchegorsk there are unveiling basic and ultrabasic intrusions containing sulphide horizons with nickelcopper-ferrous mineralization. They mainly occur as sulphide and chromite deposits. The rocks also contain PGE mineralization. They form picturesque hills located on Lake Imandra in the vicinity of Monchegorsk. 
These intrusions are about 2.4 Ga old $[6,7,15,17]$. They represent a complex of pyroxene and olivine cumulates with a noticeable layering. It can be observed in geochemical changes of minerals and the cyclicality of the rocks. These processes reflect stages of crystallization in a large igneous intrusion and play the major role in understanding the evolution of igneous rocks in the Earth interior during their migration and freezing. These massifs are clearly visible. They occur in the vicinity of the St. Petersburg-Murmansk road leading to Finland and Norway. Its southwestern end is within the protected zone of the Lapland Nature Reserve. The vegetation is similar to that of the Khibiny or Lovozero massifs. Near occurrences of ore-bearing rocks, the vegetation usually shows adaptive changes. It deserves attention when determining the response of vegetation to a substrate containing many heavy metals. The vegetation becomes poorer due to the developed industry, but westwards it gets wild and virtually untouched.

The Lapland Granulite Belt =- the Proterozoic collision zone in the vicinity of Kandalaksha. In the Kandalaksha area and southwest of Monchegorsk, there is a large collision zone of two archaic Kola and Belomorian blocks. This zone is called the Lapland Granulite Belt. It is composed of a rock series typical of subduction areas, including the volcanic rocks with amphibolite and anorthosite massifs $[6,7,8,9,17]$. These rocks occur in the Murmansk region and continue northwards in Finland and Norway (disappearing under the younger Scandinavian rock mass). This zone is peculiar with its ground stage associated with the collision of continents and the metamorphism of these rocks. It occurred in the period of 2.8-2.4 Ga, while the geothermal degree was higher than nowadays $[6,7]$. In the Kandalaksha region this part of the object is strongly tectonized and shelled. It comprises a series of metamorphosed extrusive rocks represented by amphibolites with grenades and a series of bright granites corresponding to metasets. In the south-eastern part there is a block of anorthozites from the Kolvitsa region with numerous intrusions containing ores with a magnetite composition - ilmenite along with PGE mineralization and associated charnockite intrusions [16]. Due to the natural environment in the discussed region, the vegetation here is well-preserved that differs from the counterpart of the Khibiny. Taiga follows up forest tundra and tundra only in the highest parts of the mountains. Many islands in the bottom of the White Sea have attractive vegetation associated with tides and many birds' nests. Seals and other marine animals are found in the coastal zones. In the western part of LPG there is taiga and tundra with many wild animals, elks, deer, reindeer and bears. This area is protected in both cases.

A complex of alkaline rocks in the Khibiny massif. The Khibiny massif is located in the central part of the Kola Peninsula. It has a very prominent postglacial structure that makes the landscape Alpinelooking. The climate is rather severe (the Arctic desert floor begins at an altitude of $700 \mathrm{~m}$ above sea level and an average annual temperature on the summits here is $-3^{\circ} \mathrm{C}$ ). The Khibiny massif is an early Paleozoic intrusion of about $350 \mathrm{Ma}$. There is an intrusion of alkaline rocks of the syenite group with an area of 1327 $\mathrm{km}^{2}[4,17]$. They are arranged in concentric circles, showing some vergence in the eastern direction. These rocks form a series dividing the massif into two parts. The external one is built of massive trahytoid syenites called khibinites, which are less frequently accompanied by other rocks. The internal part comprises foide syenites, with an ore zone between them (the third sequence), where nephelinites mainly occur. These sequences are crossed and the zones of the faults are often filled with such vein forms, as trakhytes (tinguaites) and melteigites. Some of these vein-like compositions are as thick as $3 \mathrm{~m}[4,5,7]$. Exposed rock sequences, their peculiar mineralization and clearly visible transitions make this massif a very representative scientific and didactic object. The nearby cities (Apatity, Kirovsk), railway and road (Murmansk-St. Petersburg) make it accessible to researchers. It enables conducting a wide range of geological, environmental and other research.

A complex of alkaline rocks in the Lovozero massif. The Lovozero massif is a twin central intrusion (alongside the Khibiny massif) of highly alkaline rocks. Its area is about $587 \mathrm{~km}^{2}[4,5,14]$. The massif is located in the central-eastern part of the Kola Peninsula, only a dozen or so kilometers east of the Khibiny massif. The Lovozero intrusion is surrounded by archaic mineralized granitogneisess of the Kola series and an old gabbroid layered intrusion with a sulfide and platinum ore, called the Fedoro-Pana massif. The latter is located southeast of the Lovozero massif that belongs to the Imandra-Varzuga belt [15, 17]. The massif structure is close to that of the neighboring Khibiny, with concentrically arranged alkaline rocks. 
Just like in the Khibiny, there are carbonatites in its central part. The rocks of this intrusion belong to syenites and urtites. There are twin beds with the Khibiny massif with plagioclases, apatite and aegirine in the background, along with zircon silicates represented by eudialyte, lorenzenite and sometimes murmanite and other rare minerals. Most rocks of the Lovozero massif have a distinct foliation, typical porphyric form structures and skeletal minerals (indicative of metasomatic connotations). These rocks have a better readable mineralization of zirconium silicates and minerals that carry trace and rare elements, including $\mathrm{Ce}, \mathrm{Nb}$ and Ag admixture [176]. The outer zone of the massif contains lujavrite, while the inner zone is composed of urtites and iolites. In this massif, the transition belt is not so strongly marked, although there are numerous veins and pegmatites.

A complex of alkaline rocks of the Afrikanda massif. Located in the southern part of the Peninsula, the alkaline-ultramafic massif of Afrikanda is about $40 \mathrm{~km}$ north of the White Sea. It is on the southern shore of Lake Imandra, $35 \mathrm{~km}$ south of the Khibiny and about $100 \mathrm{~km}$ east of Kovdor [10, 11, 18]. The Afrikanda massif has the form of a single hill with several peaks. It is a small area of $6.4 \mathrm{~km}^{2}[4,12,13]$. The massif is a Paleozoic intrusion (dated $364 \mathrm{Ma}$ ) of the same age as the other intrusions in the Kola Peninsula. It is made of various types of alkali, alkaline and ultrabasic rocks. There are numerous carbonatites, including the rare perovskite mineralization along with phases rich in REE. The central intrusion of the alkaline-cultivar rocks of Afrikanda occurs among biotite gneisses and amphibolites of the Kola series. This intrusion has an isometric shape and is characterized by a distinct zonal-ring structure. It occurs as a small hill with a morphologically uneven surface, which results in a selective resistance of the rocks to weathering. On the surface there are commonly grainy pyroxenites resistant to atmospheric factors. They are accompanied by calcite-amphibole-pyroxene rocks with magnetite and perovskite. Analyzing the geological structure of the Afrikanda massif, it is possible to distinguish two zones, i.e. the external and internal ones. The outer ring consists of melteigites, which are best seen in the peripheral part of the massif on the eastern side. They are dark grey streaky rocks made of aegirine-diopside and nepheline. Secondary minerals are grenades, ordinary hornblende, biotite, apatite and titanite. Next, there are fine-grained massive pyroxenites colored black green, sometimes with apatite layers. These rocks almost exclusively consist of diopside and hedenbergite with an admixture of magnetite, perovskite, apatite and fluorite. Towards the middle of the massif, fine-grained pyroxenites are gradually replaced by coarse-grained varieties. They are green-grey rocks consisting of diopside-hedenbergite, perovskite and magnetite with phlogopite, hornblende, titanite, penine, clinochlore and calcite as secondary minerals. In the central part of the massif, there are coarse pyroxenites, ferro-olivinites and calcite-amphibole-pyroxene rocks cut with numerous alkaline pegmatites.

\section{Discussion}

The most important advantage of the Murmansk rocks is their age. Currently, it is the oldest known rock formation in Europe and is definitely worth seeing. Second, it benefits with the association indicating that liquid water and possibly the first living organisms must have existed on the Earth, which the Issua formation confirms as well. Notably, these rocks are well-exposed and often produce picturesque walls and sharp forms in the Kola Gulf area, which can be seen from slopes. Another advantage is the developed city infrastructure and easy access to these facilities; it is enough to put a pair of boards and viewing platforms. The construction of a geocenter with a museum advances. In terms of nature, these massifs are overgrown with taiga passing into the forest and tundra.

Ultra-basic and alkaline rocks are major tourist attractions of the Monchegorsk area. Their layering indicates numerous processes accompanying cooling of batolitas, and interesting sulfide horizons with a rare and valuable mineralization. There are also well-observed rare peridotite rocks. One can easily trace the rock transitions right in situ.

The Kandalaksha area is attractive for tourists with its variety of rocks associated with the collision zone and tectonic modifications that can be seen in numerous natural exposures. The discussed rocks provide evidence of an important stage of the European craton consolidation. It superimposes the latest forms associated with the recent glaciation and retreat of the sea. The White Sea coast is associated with the Pomors that established numerous settlements in this area. Many of them preserved their authentic view, 
such as Varzuga with a church complex or the Solovetsky Islands located further south. In the Kandaksha region there were also the Karelians. Among the coastal rocks at the White Sea, numerous rock labyrinths have been preserved, constituting large historical attractions of the region. In Kandalaksha medicinal clays can be found as well.

The Khibiny massif, the highest one in the discussed area, wins scores with its picturesque nature. It is also much attractive for visitors due to the best developed tourist infrastructure in the region, offering an opportunity to spend time in summer and winter. The massif allows you to trace different sequences of well-exposed rocks. An additional advantage is numerous geomorphological forms that can be observed here. The Khibiny Mountains are an example of multiculturalism in the region. Many geographical names refer to the indigenous population of Lapland, the Lopars and Karelians. The history of mining industry in this area is very important and appreciated, since the discovery of valuable apatite ore boosted development of the area. The history is highlighted in a multimedia museum in Kirovsk fairly well.

The main tourist attraction of the Lovozero massif is a wide range of rocks with rare mineralization. There are also numerous transitions that allow tracing important geological changes of this central intrusion. Numerous post-glacial forms and an accumulation of post-glacial sediments still overlap with the discussed rocks. All this makes this region extremely interesting in terms of tourism. The Lovozero area is the historical setting of the Lopars, who settled in the nearby towns of Lovozero and Revda. They had their own clusters, ethnographic museums and some cultural and tourist facilities, like show villages with souvenirs. The Lopars' history reflected in some geographical names of the massif and minerals, e.g. loparite, "the Lopars' blood". The ethnographic aspect superimposes on the history of mining development in this area, which also deserves attention.

From this place roads run towards wilder nooks of the Kola land. It is the so called Kola interior with an extremely small number of people living there. Afrikanda is located in the southern part of the peninsula. It is overgrown with spruce and pine forests with an admixture of juniper, rowan and birch. Typical species characteristic of the entire region are dominant in the swamp. The most important asset of this place is the now closed quarry with numerous ultra-ground rocks, magnetite ores and the occurrence of perovskite. There are also numerous rare minerals in addition to the perovskite, e.g. schorlomite and many others. In the quarry and nearby places one can trace the geological structure of this small intrusion.

\section{Conclusion}

The discussed areas are just some examples of interesting objects in the Murmansk region. These have some specific features, being relatively close to the available infrastructure (roads, railways, cities), rather easy to visit and representative as geological exposures. In these terms, Murmansk is best-suited, since there are the Europe-oldest rocks and most tourist facilities, including hotels. The Khibiny massif hosts many tourists as well, but making it a geopark is quite a challenge due to the conflict of interests of mining plants and the current lack of protection. The situation would be similar with regard to many other objects, but it can change if local authorities become convinced that protection and tourism would not hinder the sustainable development. An abandoned quarry in Afrikanda is another promising object. It is an unusual place in a dreadful state, but relatively easily can be restored to a good condition. It goals with the proximity of Polarniye Zori, the town of energetics, and an international railway.

\section{References}

1. Kola Superdeep. Research of the deep structure of the continental crust using the Kola Superdeep Borehole drilling. M: Nedra. 1984. 490 p. (in Russian).

2. Kola Superdeep. Scientific results and study experience. M.: MF „Tekhnoneftegas”, 1998. 260 p. (in Russian).

3. Structure, properties, conditions of rocks and geodynamics in geospace of the Kola Superdeep Borehole (SD-3) / Edit. By Gorbatsevich F.F. /StP.: Nauka. 2015. 366 p. (in Russian).

4. ARZAMASTSEV A.A., 1995. Paleozoic plutonic complexes. In: Mitrofanov, F.P., Geology of the Kola Peninsula. Apatity. P. 85-103.

5. Agaphonov L.V., Chepurov A.I., Lavrent'ev Yu.G., Pokachalova O.S., 1974. Regularly oriented inclusions in olivine from ultrabasites of Koriakiya. Geol. Geophys. V. 6. P. 49-60 (in Russian). 
6. Bayanova T.B., Pozhylienko V.I., Smolkin V.F., Kudryshov N.M., Kaulina T.V., Vetrin V.R. 2002. Catalogue of the geochronological data of the NE part of the Baltic Shield. Apatity. P. 53 (in Russian).

7. Bayanova T.B. 2004. Age of reference geological complexes of the Kola Peninsula and duriation of the magmatic processes: St. Petersburg, Nauka. P. 174 (in Russian).

8. Huber M., Hałas S., Sikorska M. 2007. Evolution of prehnite albite-calcite veins in Metamorphic rocks from the Lapland Granulite Belt (Kandalaksha region of Kola Peninsula). Geologija. V. 57: P. 1-7.

9. Huber M.A. 2014. Geology of the Lapland Granulite Belt of the Kandalaksha region, Kola Peninsula, Russia, TMKarpinski Publisher. P. 135 (in Polish).

10. Huber M.A., Lata L. 2015. Mineralogy and petrographic characteristic of carbonate samples from Kovdor (Kola Peninsula, N Russia). JBES 5(1): P. 34-89.

11. Homenko V.M., Platonov A.N., Krasnova N.I., 1991. The optical properties of phlogopite of the Kovdor massif. Izv. Akad. Nauk SSR, Ser. Geologicheskaya. V. 12. P. 94-105 (in Russian).

12. Kogarko L.N., 1987. Alkaline rocks of the eastern part of the Baltic Shield (Kola Peninsula), Geological Society, London, Special Publications. V. 30. P. 531-544.

13. Kogarko L.N., Ryabchikov I.D., 1969. Differentiation of alkaline magmas rich in volatiles. Geochem. Int. 6. P. 2011-2021.

14. Kramm U., Kogarko L.N., Kononova V.A., Vartiainen H. 1993. The Kola Alkaline Province of the CIS and Finland: precise Rb-Sr ages define 380-360 Ma age range for all magmatism. Lithos 30. P. 33-44.

15. Mitrofanov F.P., Balashov Yu.A., 1990. Geochronology and genesis of layered basic intrusions, volcanites and granite -gneisses of the Kola Peninsula. RAS, Apatity.

16. Neradovsky Yu.N., Groshev N.Yu., Voytekhovsky Yu.L., Borozdina S.V., Savchenko Ye.E., 2017. First discovery of platinium, palladium, silver and gold minerals in tytanomagnetite ore of «Zheleznyi» massif (Kola Pen., N Russia), Geo-Science Education Journal; 2 (5): P. 1-15.

17. Pozhilienko V.I., Gavrilenko B.V., Zhirov D.V., Zhabin S.V. Geology of mineral areas of the Murmansk region. Apatity, RAS. 2002: 360.

18. Sulimov B.I., Kolcova T.P., Nechayev S.A., Afanaseva N.V., Dombrovskaya T.P., 1999. Schematic geology map of the Kovdor massif, Murmansk region, Kovdor Mine Press. 